\title{
Effect of Supplementation of Mulberry Hay with Sorghum Straw on Nutrient Utilisation and Growth in Crossbred Calves
}

\author{
Venkateswarlu Malisetty ${ }^{1}$, Narasimha Jatoth ${ }^{2}$, \\ ${ }^{1,2}$ Department of Animal Nutrition, College of Veterinary Science, \\ Sri Venkateswara Veterinary University, Rajendranagar, Hyderabad, Andhra Pradesh, India
}

\begin{abstract}
The average daily gains $(A D G)$ were found to be 510.3 and $511.8 \mathrm{~g} /$ day, respectively on ration 1 and 2 and were non significant. The DM intake per $\mathrm{kg}$ live weight gain $(\mathrm{kg})$ was 7.47 and 7.59 recorded with ration 1 and 2, respectively. The voluntary daily feed intake $(\mathrm{kg})$ of 3.25 and $3.43 \mathrm{per} 100 \mathrm{~kg}$ body weight was observed with ration 1 and 2, respectively. Supplementation of mulberry hay as mixed fodder decreased the digestibilities of DM, OM, CF (P<0.01) and an increased digestibility of $C P(P<0.05)$. No significant difference in the digestibilities of EE and NFE were observed among the two rations. Based on the results, this study revealed that mulberry hay was palatable, improved the nutrient utilization of straw rations and could be safely supplemented at 50\% level, as leguminous component of the diet and feed cost can be reduced by saving $0.66 \mathrm{~kg}$ of concentrate per animal per day in growing crossbred calves.
\end{abstract}

Key words: Mulberry hay, Sorghum straw, Nutrient utilisation, Growth rate, Crossbred calves

\section{Introduction}

India being an agricultural country with a large population of livestock consisting of 210.2 million cattle and 111.3 million buffaloes [1]. Present potential availability of dry roughages, green fodder and concentrates in the country is to the extent of $393.38,462.05$ and 35.32 million tonnes, respectively [2]. It was estimated that, India is deficit in dry fodder by $13 \%$, green fodder by $33 \%$ and concentrates by $25 \%$ [3]. Crop residues like straws, Kadbies and stovers form the major components of livestock diet in India. The main limiting factor in their utilization is due to their low palatability, protein and energy content. Supplementation of leguminous fodders with crop residues improve the digestibility and nutrient utilization and lowers the production cost of animal industry.

Mulberry is a shrub or tree traditionally used in sericulture in various countries. It belongs to the order Urticales, the family Moraceae and the genus Morus. There is an estimated 68 species of the genus Morus with the majority of them occurring in Asia [4]. The most common species are M. alba, the white mulberry (M. nigra), black mulberry (M. rubra), red mulberry (M. indica). Mulberry (Morus alba) crop is grown widely in some districts of Andhra Pradesh where sericulture is common. Mulberry is a perennial shrub, cultivated as a plantation crop. The annual yield of this crop is about 8-10 tonnes/acre. The area under cultivation of this plantation crop in Andhra Pradesh state is 1, 83,538 acres (Department of Sericulture, Government of Andhra Pradesh). Although most of it is used for silkworm industry, left overs and crop residues are used for feeding livestock in the villages. In this investigation, an attempt was made to study the effect of supplementation of mulberry hay with the chopped sorghum straw (1:1 ratio) on growth rate and digestibility of the nutrients in crossbred calves.

\subsection{Preparation of Experimental Rations}

\section{Materials and Methods}

Two experimental rations used are chopped sorghum straw ad libitum + concentrate mixture to meet the requirement (Ration 1) and chopped sorghum straw and chopped mulberry hay in 1:1 ratio ad libitum + concentrate mixture to meet the requirement (Ration 2). The chopped sorghum straw (8mm size) was obtained from local market and used for feeding the calves. The mulberry fodder was harvested on $50^{\text {th }}$ day after seventh cut and was chopped to 10-12 mm size. The chopped fodder was dried under shade and preserved in gunny bags for feeding to the calves. The concentrate mixture was proportioned in $100 \mathrm{~kg}$ batches as per formula (Table 1). The ingredients requiring grinding were ground in hammer mill using $8 \mathrm{~mm}$ sieve. The ingredients, mineral mixture and vitamin supplement were mixed in horizontal batch mixer.

Table 1. Ingredient composition of concentrate mixture

\begin{tabular}{|l|c|}
\hline Names of Ingredients & Quantity (kg) \\
\hline Maize grains & 30 \\
\hline Groundnut cake & 20 \\
\hline
\end{tabular}




\begin{tabular}{|l|c|}
\hline Wheat bran & 24 \\
\hline Deoiled rice bran & 23 \\
\hline Common salt & 1 \\
\hline Mineral mixture* & 2 \\
\hline Rovimix** & 100 \\
\hline Total Contained Ca, 20.8\%; P6.2\%; Salt 35.8\%; Iron 0.4\%;Iodine 250 ppm; Manganese 740 ppm;
\end{tabular}

$\begin{array}{lllllllllll} & \mathrm{Cu} 280 \text { ppnm and sulphur } 0.15 \% \text {. } & & & & & & & & \end{array}$ per $\mathrm{kg}$ was added at the rate of $20 \mathrm{~g}$ per $100 \mathrm{~kg}$ of concentrate mixture.

\subsection{Growth Studies}

\subsubsection{Selection and Distribution of Experimental Animals}

Twelve crossbred (Ongole X Holstein Friesian) heifer calves 6-12 months of age, weighing 69.0 to $149.0 \mathrm{~kg}$ obtained from dairy experimental station, Rajendranagar, Hyderabad, India. The animals were randomly divided into two groups, containing six animals in each group in such a way that the group average body weights were 103.29 \pm 5.58 (Ration 1) and 103.92 \pm 12.58 (Ration 2). The two experimental rations were allotted to two groups of animals.

\subsubsection{Housing, Feeding and Watering Management of Animals}

All the animals were housed in a well ventilated shed with provision for individual feeding and with an open yard outside. The animals were dewormed at the beginning of the experiment and once again after 3 months of the commencement of the experiment. Throughout the experimental period healthy surroundings and proper cleanliness were maintained in experimental shed. Experimental rations 1 and 2 were randomly assigned to 2 groups of animals. All the experimental animals were fed with respective experimental rations for a period of 180 days. The animals on ration 1 were fed chopped sorghum straw ad libitum and concentrate mixture to meet the requirements, based on body weight of the animals. The animals on ration 2 were fed $a d l i b$ mixed fodder comprising mulberry hay and chopped sorghum straw in 1:1 ratio and concentrate mixture to meet the requirements, based on body weight of the animals. The animals were offered the respective rations at 9 AM and 3PM. The residues if any, were weighed on the next day morning. Clean and wholesome water was made available to each animal twice daily. The DM content of feeds offered and residues was estimated to arrive at exact quantity of feed consumed.

\subsubsection{Live Weight Recording}

Initial weight of the animals were recorded at the beginning of the growth experiment and then the weights are recorded at every fortnightly before feed and water was offered. At the end of the experiment average daily gain was calculated by using the formula.

Average daily gain $(\mathrm{kg})=$

Final weight $(\mathrm{kg})$-- Initial weight $(\mathrm{kg})$

$$
\text { Number of days (180) }
$$

\subsection{Digestion Studies}

A digestion trial was conducted on all 12 animals which were in the experiment to assess the nutrient digestibility of the 2 rations during the middle of the growth experiment. A7-day collection period was conducted during which faecal and feed samples were collected and stored for further analysis.

\subsubsection{Sampling of Feed and Feed Residues}

Representative samples of each of the 2 rations were taken every day before feeding to the animals and estimated the dry matter by drying in hot air oven at $100 \pm 5^{\circ} \mathrm{C}$ over night. These samples were pooled for 7 days and ground in a laboratory Wiley mill and preserved in polythene bags for subsequent analysis. Similarly representative samples of feed residues of each ration were collected every day, for its DM estimation.

\subsubsection{Collection of Faeces}

Faeces as and when voided were collected carefully into separate containers (Buckets) which were closed with tight lids to prevent drying. The total quantity of faeces voided during 24 hours period was weighed daily at 9.00 a.m. The faeces thus collected was thoroughly mixed and a representative sample was taken from each animal into a bottle (approximately $500 \mathrm{~g}$ ) and carefully carried to the laboratory for analysis. 


\subsubsection{Aliquoting and Preservation of Faeces}

For nitrogen estimation, $1 / 100^{\text {th }}$ part of the faeces voided each day by individual animal was weighed, mixed with sufficient quantity of 25 per cent sulphuric acid and preserved in previously weighed air tight stoppered sample bottles. Daily samples were preserved in the same labelled bottles. After a 7-day collection period, the weights of the sample bottles were recorded and the samples were analysed for nitrogen content. For DM estimation, an aliquot of 1/10 th part was taken into petridishes from the individual animals separately and dried in a hot air oven overnight at $100 \pm 5^{\circ} \mathrm{C}$. The dried samples were pooled, ground in a laboratory Wiley mill and stored in polythene bags separately for subsequent analysis.

\subsubsection{Analytical Methods}

Estimation of dry matter, organic matter, crude protein, ether extract, crude fibre, nitrogen-free extract and total ash was done [5]. The metabolisable energy content of the rations was calculated using the factors recommended by NRC (1978, DE X 0.82). The experimental data were analysed by appropriate methods [6].

\subsection{Chemical composition of experimental ration}

\section{Results}

Proximate composition of concentrate mixture, mulberry hay, chopped sorghum straw (Sorghum kutti) and mixed fodder comprising chopped Sorghum straw and mulberry hay in 1:1 ratio is presented in Table 2.

Table 2: Chemical composition of experimental feeds ( $\%$ on dry matter basis)

\begin{tabular}{|l|c|c|c|c|}
\hline \multicolumn{1}{|c|}{ Nutrient } & Concentrate mixture & Mulberry hay & $\begin{array}{c}\text { Chopped } \\
\text { sorghum straw }\end{array}$ & Mixed fodder \\
\hline Dry matter & 93.42 & 95.26 & 94.85 & 94.57 \\
\hline Organic matter & 87.61 & 89.65 & 88.80 & 89.37 \\
\hline Crude protein & 17.86 & 12.74 & 4.17 & 8.46 \\
\hline Ether extract & 3.51 & 4.73 & 1.43 & 2.96 \\
\hline Crude fibre & 6.90 & 25.72 & 31.58 & 29.07 \\
\hline Nitrogen-free extract & 59.34 & 46.46 & 51.62 & 48.88 \\
\hline Total ash & 12.39 & 10.35 & 11.20 & 10.63 \\
\hline
\end{tabular}

Each value is a mean of two observations

\subsection{Digestibility studies}

Dry matter, organic matter, crude protein, crude fibre, ether extract and nitrogen free extract digestibilities of ration 1 and ration 2 were presented on table 3 . The dry matter and organic matter digestibilities were significantly $(\mathrm{P}<0.01)$ different among the rations. Ration 1 having more digestibilities might be due to more intake of concentrate mixture. The crude protein digestibility was significantly $(\mathrm{P}<0.05)$ higher in ration 2 in comparison to ration 1 . This higher $\mathrm{CP}$ digestibility in ration 2 could be due to inclusion of high quality mulberry hay in ration 2 . The $\mathrm{CF}$ digestibility coefficients were decreased significantly $(\mathrm{P}<0.01)$ from ration 1 to ration 2. The EE and NFE digestibilities were comparable among the two rations fed to crossbred calves.

Table 3. Average digestibility coefficients and nutritive value as affected by experimental rations in crossbred calves

\begin{tabular}{|c|c|c|}
\hline \multirow[t]{2}{*}{ Parameter } & \multicolumn{2}{|c|}{ Experimental Rations } \\
\hline & Ration 1 & Ration 2 \\
\hline Animal weight (kg) & 149.18 & 149.92 \\
\hline DM intake/day (kg) & 5.59 & 5.15 \\
\hline DMI/100kg weight (kg) & 3.25 & 3.43 \\
\hline Water intake/kg DMI (lits) & 4.05 & 3.91 \\
\hline \multicolumn{3}{|l|}{ Nutrient digestibility (\%) } \\
\hline Dry matter $* *$ & $62.52^{\mathrm{a}} \pm 0.78$ & $57.36^{\mathrm{b}} \pm 0.60$ \\
\hline Organic matter** & $65.16^{\mathrm{a}} \pm 0.68$ & $61.85^{\mathrm{b}} \pm 0.53$ \\
\hline Crude protein* & $69.05^{\mathrm{b}} \pm 0.87$ & $71.79^{\mathrm{a}} \pm 0.65$ \\
\hline Crude fibre** & $61.06^{\mathrm{a}} \pm 0.82$ & $52.45^{\mathrm{b}} \pm 0.56$ \\
\hline Ether extract & $62.88 \pm 1.54$ & $62.16 \pm 0.89$ \\
\hline Nitrogen-free extract & $66.22 \pm 1.01$ & $64.85 \pm 0.75$ \\
\hline \multicolumn{3}{|l|}{ Nutritive value (\%) } \\
\hline $\mathrm{DCP} * *$ & $6.74^{\mathrm{b}} \pm 0.11$ & $7.92^{\mathrm{a}} \pm 0.04$ \\
\hline TDN & $59.13 \pm 0.64$ & $57.77 \pm 0.39$ \\
\hline
\end{tabular}


Each value is a mean of six observations

a, b values with different superscripts differ significantly $*(\mathrm{P}<0.05) ; * *(\mathrm{P}<0.01)$

\subsection{Growth studies}

The data pertaining to dry growth performance, dry matter intake and feed efficiency are presented in Table 4. The minimum and maximum total weight gains $(\mathrm{kg})$ were 77.75 and $109.50 ; 75.83$ and 105.00 were recorded in the animals of group 1 and 2, respectively during the experimental period of 180 days. The average daily gain was 510.00 and $511.67 \mathrm{~g}$ in crossbred calves fed rations 1 and 2, respectively which were comparable among the rations. The average total dry matter intake $(\mathrm{kg}), \mathrm{DMI}(\mathrm{kg}) / \mathrm{animal} / \mathrm{day}, \mathrm{DMI}(\mathrm{kg})$ per $100 \mathrm{~kg}$ body weight non significantly different among two experimental rations fed to crossbred calves. The average dry matter consumption $(\mathrm{kg})$ per $\mathrm{kg}$ live weight gain (feed efficiency) was also not significantly $(\mathrm{P}>0.05)$ different among the two rations.

Table 4. Growth performance and feed efficiency in crossbred calves as affected by experimental rations

\begin{tabular}{|l|c|c|}
\hline \multirow{2}{*}{ Item/parameter } & \multicolumn{2}{c|}{ Experimental rations } \\
\cline { 2 - 3 } & Ration 1 & Ration 2 \\
\hline No.of animals & 6 & 6 \\
\hline Experimental period (days) & 180 & 180 \\
\hline Initial weight (kg) & 103.29 & 103.92 \\
\hline Final weight (kg) & 195.14 & 96.05 \\
\hline Weight gain in 180days (kg) & 91.85 & 511.83 \\
\hline Average daily gain (ADG) (g) & 510.27 & 699.33 \\
\hline DMI during 180 days (kg) & 686.35 & 3.88 \\
\hline DMI/animal/day (kg) & 3.81 & 2.59 \\
\hline DMI/100kg body weight (kg) & 2.55 & 7.59 \\
\hline $\begin{array}{l}\text { DMI/kg live weight gain }(\mathrm{kg}) \\
\text { (Feed efficiency) }\end{array}$ & 7.47 & \\
\hline
\end{tabular}

Each value is a mean of six observations; No significant $(\mathrm{P}>0.05)$ difference was observed between the experimental rations

\subsection{Chemical composition of the experimental feeds}

\section{Discussion}

In the present study the mulberry fodder was chopped and dried in shade. This chopped hay was supplemented with chopped sorghum straw in the ratio of 1:1 (mixed fodder). The composition of mulberry hay is comparable to sorghum straw with respect to DM, OM and NFE. The protein (CP) content was higher by 8.57 per cent. The composition recorded in this study was comparable to the reports of [7], [8], [9], [10] and [11]. The chemical composition of mulberry hay was comparable to conventional legume fodder and hence, can be supplemented to the straws. Chemical composition of chopped sorghum straw used in this experiment concurred with the values of earlier reports [12], [13] , [14].

\subsection{Digestion studies}

\subsubsection{DM digestibility}

The DM digestibility was significantly $(\mathrm{P}>0.01)$ lower on ration 2 as compared to ration 1 . Increased DM digestibility on ration 1 compared to ration 2 was a reflection of nutrient digestibility due to increased consumption of concentrate mixture. DM digestibility of ration 2 was 57.36 per cent, which is higher than the reports of [15]. They reported the sorghum straw DM digestibility was near to 50 per cent. This increase in the digestibility might be due to supplementation of mulberry hay in the ration 2 . Similar results were reported with sorghum hay in cows [16]. Supplementation of lucerne or berseem with sunflower straw improved the DM digestibility of ration in goats and sheep [17].

\subsubsection{OM digestibility}

The significant $(\mathrm{P}<0.01)$ increase of $\mathrm{OM}$ digestibility by 3.31 per cent with ration 1 as compared to ration 2. This might be due to fewer intakes $\mathrm{OM}$ through roughage component of the ration 1 . The mean digestibility coefficients of $\mathrm{CP}$ of ration 1 was lower $(\mathrm{P}<0.05)$ by 2.71 per cent as compared to ration 2 . The higher value in ration 2 was attributed to higher intake of protein through roughage portion/component of the ration and also due to more DCP content of mulberry hay as compared to sorghum straw. The increased CP digestibility was reported on sun hemp hay based rations in bullocks [18], [19]. 


\subsubsection{CF digestibility}

Though the DMI was higher with ration 1 as compared to ration 2, the CF intake was lower and the digestibility of $\mathrm{CF}$ (Table 3 ) was $8.61 \%$ higher $(\mathrm{P}<0.01)$ with ration 1 than ration 2 . This decrease digestibility in ration 2 may be attributed to higher intake of $\mathrm{CF}$, through higher roughage intake. Similar higher $\mathrm{CF}$ digestibility was recorded [20], [15], [12], in hybrid sorghum kadbi (sorghum vulgare) in dairy heifers and on the contrary lower CF digestibility was reported [21] with sorghum in buffalo calves. However supplementation of sun hemp hay meal/ subabul leaf meal [22] and berseem to jowar straw improved the utilisation of crop residues in the rations of crossbred calves.

\subsubsection{EE digestibility}

Higher ether extract intake on ration 2 was due to higher EE content of mulberry hay. However, there was no significant difference in the digestibility coefficients of EE between the two rations. These results are corroborative with those reported [23] where they found non significant difference between the experimental rations in complete diets of cattle containing crop residue mixtures and these results are in contrast with the observation of [24] where it was replaced increased EE digestibilities for complete mash feeds containing 46 per cent sorghum straw. [25] also recorded no significant difference in EE digestibilities when fed cowpea hay in buffalo calves. Similar EE digestibilities were recorded [26] in goats, fed subabul supplemented diet.

\subsubsection{NFE digestibility}

Increased NFE intakes on ration 1 may be attributed to high levels of NFE in the concentrate mixture as compared to ration 2. However, there is no significant difference in the NFE digestibilities among the two rations. These NFE digestibility were comparable with [27] fed pillipesara hay, [8] fed mulberry leaf stalk and [28] fed cowpea hay in rams. Though the NFE digestibility was lower with ration 2 as compared to ration 1, but there was an improvement in the digestibility of NFE to that of jowar straw. These results are comparable with the results reported by [10] and [11] in crossbred cattle fed mulberry hay as sole ration and mulberry hay with urea treated sunflower straw respectively.

\subsection{Growth studies}

The average daily gains (ADG) recorded on both the rations was not significantly different. However, the weight gains recorded on ration 2 were on par with the ration 1 indicating mulberry hay can be supplemented to straw at 1:1 ratio for growing crossbred calves. The DM intake per kg weight gain (feed efficiency) was 7.47 and 7.59 for the rations 1 and 2, respectively in crossbred calves indicating that both the rations were palatable where the mulberry hay was replaced with $0.66 \mathrm{~kg}$ of concentrates per animals per day. The weight gains recorded in this investigation are at par with the reports of [29], [30] on complete ration with 50 percent wheat straw in crossbred calves. [31] on subabul green foliage with rice straw in crossbred calves, [32] on rye grass plus lucerne hay in crossbred heifers. However, the lower weight gains were recorded by [19] with rumen degradable protein in crossbred female calves, [33] on different percentages of urea in a diet in crossbred calves. And higher weight gains were reported by [34] fed leucaena in buffalo calves, [35] in buffalo calves fed concentrate mixture and wheat straw, [14] fed sorghum straw and sun hemp hay in crossbred heifers. The minimum and maximum daily weight gains were 432 and 608; 421 ad 583 in group 1 and 2, respectively. This variation in gains could be due to differences in age of the animals. However, the average daily gain did not differ significantly though there is a much variation in daily gains between the animals, within a group.

\subsection{Feed efficiency}

Feed efficiency (DM intake per kg weight gain) did not differ significantly among the two groups indicating that the mulberry hay could replace concentrate mixture $0.66 \mathrm{~kg}$ per animal per day at 1:1 ratio (sorghum straw: mulberry hay) in the crossbred calves. These results indicates, better utilization of nutrients, with wider concentrates: roughage, ratio on ration 2 as compared to ration 1 . The feed efficiency values were optimum and comparable to the reports of [31] in crossbred calves fed leucaena foliage. However, increased feed efficiency was reported by [22] in crossbred heifers fed sorghum straw plus sun hemp hay. The results of growth study indicate that $0.66 \mathrm{~kg}$ of concentrate mixture per animal per day could be saved by mulberry hay supplementation in growing crossbred calves.

\section{Conclusion}

Based on the results of this investigation it is inferred that, mulberry hay is palatable, improves the nutrient utilization of straw rations and can be safely supplemented at 50 per cent level as a leguminous component of the diet and supplementation of mulberry hay to jowar straw, feed cost can be reduced by saving $0.66 \mathrm{~kg}$ concentrate mixture per animal per day in growing crossbred calves. 


\section{References}

[1] F.A.O, 2010, Food and Agricultural Organisation, Rome, Italy.

[2] K.T. Sampath, K.S.Ramachandra, and S. Anandan, Livestock feed and fodder resources of India and strategies for their judicious utilisation- A review. Indian Journal of Animal Science, 75 (12), 2005, 1438-1443.

[3] P.S. Birthal, and A.K Jha, Review on emerging trends in India's livestock economy: Implications for development policy. Indian Journal of Animal Science, 75 (10), 2005, 1227-1232.

[4] R.K.Datta,R.K,MulberryCultivationandUtilizationinIndia, 2001.http://.fao.org/waicent/faoinfo/agricult/agap/frg/mulber.../Datta.tx

[5] A.O.A.C, Official Methods of Analysis $16^{\text {th }}$ edition, Association of Official Analytical chemists, 1997, Washington, DC.

[6] G.W.Snedecor, and W.G. Cochron, Statistical methods ( $8^{\text {th }}$ edition), 1989, Oxford and IBH publishing Corporation, Calcutta.

[7] M.M. Jayal, and N.D. Keher, A study on the nutritive value of mulberry (Morus alba) tree leaves. Indian Journal of Dairy Science, 15, 1962, 21-27.

[8] A Subbarao, M.N. Amrith Kumar, and S.R. Sampath, Studies on mulberry (Morus indica) leaf-stalk palatability, chemical composition and nutritive value. Indian Veterinary Journal, 48, 1971, 853-857.

[9] E. Prasad, and M.R. Reddy, (1991). Nutritive value of mulberry (Morus alba) leaves in sheep and goats. Indian Journal of Animal Nutrition, 8(4), 1991, 295-296.

[10] K. Venugopal Rao, Nutritive evaluation of mulberry (Morus alba) hay meal for crossbred cattle, MVSc thesis, 1992, Submitted to Andhra Pradesh Agricultural University, Hyderabad, India.

[11] M Shankar Rao, Supplementation of urea treated suflower straw with mulberry hay in the rations of crossbred cattle. MVSc thesis, 1994, Submitted to Andhra Pradesh Agricultural University, Hyderabad, India.

[12] B.S. Waghmore, V.C. Badve, A.L. Joshi, and D.V. Rangnekar, Steam treatment of hybrid sorghum kadbi (Sorghum vulgare) for feeding cattle. Indian Journal of Animal Nutrition, 4, 1987, 166-169.

[13] M. Chandrasekharaiah, Studies on the effect of of physical factors on the utilisation of nutrients of jowar straw among sheep and goats, MVSc thesis, 1989, submitted to Andhra Pradesh Agricultural University, Hyderabad, India.

[14] N.M. Reddy, G.V.N. Reddy, and M.R. Reddy, Utilisation of fodder based complete diets in crossbred bulls, Indian Journal of Animal Science, 64(6), 1994, 631-635.

[15] A.Rekib, A.P. Singh, V.S.Upadhyay, and B.K.Bhadoria, A note on fortification of sorghum stovers with urea mineral mixrure, Indian Journal of Animal Science, 46, 1976, 361-363.

[16] M.H. Neitz, J.R. Zyul Van, and C.L. Hartman, The nutritive value of sorghum hay. Supplemented by concentrates in different rations and fed to high and low producing Friesland cows and first calf heifers, Nutrition Abstracts and Reviews, 52, 1982, 342347.

[17] D. Mudgal, and K. Daljit, (1986). Comparative utilisation of feed nutrients in growing goats and calves, Indian Journal of Dairy Science, 29, 1986, 151-157.

[18] D.V.Reddy, U.B.Singh, and U.R. Mohra, Effect of supplementation of ammoniated wheat straw diets with green berseem in buffaloes, Indian Journal of Animal Science, 62, 1992, 261-265.

[19] K.T. Sampath, C.S.Prasad, and M.T. Shivaramaih, Effect of feeding two levels of rumen degradable protein at higher level of energyon growth and nutrient utilisation in crossbred female calves, Indian Journal of Animal Nutrition, 10 (2), 1993, 89-93.

[20] V.V. Sharma, B.M. Jhanvar, and A.L. Taparia, Utilisation of sorghum stover by cattle, Indian Journal of Animal Science, 42, $1972,480-487$.

[21] T.R. Chauhan, and S.S.Randhawa, Comparative study on the yield and nutritive value of sorghum fodder hay, Indian Journal of Animal Science, 53, 1983, 1013-1015.

[22] K.S. Reddy, G.V.N.Reddy, and M.R.Reddy, Nutrient utilisation and growth performance of crossbred heifers fed fodder-based complete diet, Indian Journal of Animal Science, 64(8), 1994, 862-866.

[23] D.N. Reddy, and M.R.Reddy, Complete rations for sheep utilising crop residues and agro-industrial by- products, Indian Journal of Animal Science, 51, 1981, 455-457.

[24] K.J. Reddy, Processing of complete pelleted feeds utilising forest grass and agro-industrial by-products for sheep, Ph.D. thesis, 1983, submitted to Andhra Pradesh Agricultural University, Hyderabad, India.

[25] T.R. Chauhan, and A.K. Chopra, Cow pea (Vigna sinensis) hay as a replacement for conventional concentrate mixture in the rations of buffalo calves, Indian Journal of Animal Science, 56, 1986, 556-561.

[26] R.K. Yadav, C.S.Barsual, and M.L.Maheshwari, Nutritive value of subabul (leucaena leucocephala) hay for goat, Indian Journal of Animal Nutrition, 7(3), 1990, 221-222.

[27] E.C.Reddy, Studies on nutritive value of pilliipesara (Phaseolus trilobus) and its value as a supplement to paddy straw, MVSc thesis, 1969, submitted to Andhra Pradesh Agricultural University, Hyderabad, India.

[28] B.C. Patnaik, Q.R.Madan Mohan, Bhatia, and A. Hatra, A note on nutritive value of cowpea moth (Dewgram) and clusterbean fodder fed as hay to sheep, Indian Journal of Animal Science, 49, 1979, 746-748.

[29] B.S. Rao, and K. Nath, Alkali treated neem seed cake (Azadirachta indica juss) as cattle feed, Journal of Animal Science, 49 (3), 1979, 170-174.

[30] S.K.R. Reddy, and M.R.Reddy, Effect of feeding complete ration on growth and nutrient utilisation in crossbred calves, Indian Journal of Animal Nutrition, 5(3), 1988, 95-201.

[31] D.V. Reddy, N. Krishna, K.N.Naidu, and R.R.Reddy, Effect of substituting conventional concentrate mixture by Leucaena leucocephala leaf fodder in crossbred calves fed rice straw based rations, Indian Journal of Animal Nutrition, 10(1), 1993, 21-25.

[32] T.R. Chauhan, Dried ryegrass (Lolium perene) grown in combination with berseem/lucerne as a replacement for conventional concentrate mixture in the ration of buffalo bull calves, Indian Journal of Animal Science, 65(1), 1995, 7-73.

[33] R.C.Saha, and B.N. Gupta, Effect of feeding different levels of urea as protein replacer on growth and nutrient utilisation in crossbred calves, Indian Journal of Dairy Science, 42(3), 1989, 413-418.

[34] M.A.Akbar, and P.C.Gupta, Subabul (leucaena leucocephala) as a source of protein supplement for buffalo calves, Indian Journal of AnimalScience, 55, 1985, 54-58.

[35] A.S.Virka, V.K.Khatha, N.Kumar, P.C.Gupta, and I.S. Yadava, Effect of feeding subabul on growth performance of buffalo calves and their rumen metabolites, Indian Journal of Animal Nutrition, 2(1), 1985, 35-38. 